\title{
PRINSIP KESAMAAN KEDUDUKAN HUKUM DALAM PENYELESAIAN SENGKETA PAJAK DI INDONESIA
}

\author{
Hari Hasan \\ Praktisi Hukum dan Anggota Perhimpunan Advokat Indopnesia (PERADI) Kota Banjarmasin \\ Email: bghasan88@mail.com
}

Info Artikel:

Diterima: 30 maret 2020

| Disetujui: 01 Mei 2020

| Dipublikasikan: 30 Juni 2020

\begin{abstract}
Abstrak
Jenis penelitian yang digunakan dalam penelitian ini adalah yuridis normati, bersifat deskriptif analitik, yaitu menjelaskan tentang pertentangan norma antara Undang-undang Nomor 28 Tahun 2007 tentang Ketentuan Umum Tata Cara Perpajakan dengan Undang Undang Dasar Negara Republik Indonesia Tahun 1945. Hasil penelitian menyimpulkan bahwa Undang-undang Nomor 28 Tahun 2007 tentang Ketentuan Umum Tata Perpajakan tidak memberikan kepastian hukum yang adil bagi para pihak, posisi Fiskus sebagai "negara" memiliki kekuasaan (absolute power) untuk menghitung, menetapkan besaran pajak yang harus dibayarkan oleh Wajib Pajak dan membuat keputusan atas permohonan Keberatan yang disampaikan oleh Wajib Pajak. Merujuk kepada Pasal 25 ayat (9) dan Pasal 27 ayat (5d) Undangundang Nomor 28 Tahun 2007 tentang Ketentuan Umum Tata Cara Perpajakan, tidak mencerminkan prinsip Kesamaan Kedudukan Hukum (Wajib Pajak/warga negara dengan Fiskus dalam upaya memperoleh keadilan), ketentuan ini bertentangan dengan Pasal 27 ayat (1) Undang Undang Dasar Republik Indonesia Tahun 1945, pasal tersebut merupakan suatu barier terhadap warga negara yang ingin mencari keadilan. Bentuk ideal hubungan hukum Wajib Pajak dan Fiskus adalah dengan memberikan kesamaan terkait dengan punishment dan reward bagi para pihak, kesalahan perhitungan besaran pajak yang harus dibayarkan oleh Wajib Pajak tidak selalu disebabkan atas kesalahan pihak Wajib Pajak akan tetapi Fiskus secara jabatan juga dapat melakukan kesalahan baik secara sengaja ataupun tidak dalam menetapkan besaran pajak.
\end{abstract}

Kata Kunci: Wajib Pajak, Fiskus, Kesamaan Kedudukan Hukum.

PRINCIPLE OF EQUAL LEGAL POSITION IN TAX DISPUTE SETTLEMENT IN INDONESIA

\begin{abstract}
The type of research used in this research is normative juridical, descriptive analytic, which explains the conflicting norms between Law Number 28 of 2007 concerning General Provisions on Tax Procedures and the 1945 Constitution of the Republic of Indonesia. Law Number 28 of 2007 concerning General Provisions on Taxation does not provide fair legal certainty for the parties, the position of Fiskus as a "state" has absolute power to calculate, determine the amount of tax that must be paid by Taxpayers and make decisions on objection requests. submitted by the Taxpayer. Referring to Article 25 paragraph (9) and Article 27 paragraph (5d) of Law Number 28 of 2007 concerning General Provisions on Tax Procedures, it does not reflect the principle of Equality of Legal Position (Taxpayer/citizen with Fiskus in an effort to obtain justice), the provisions This is contrary to Article 27 paragraph (1) of the 1945 Constitution of the Republic of Indonesia, this article is a barrier against citizens who want to seek justice. The ideal form of legal relationship between taxpayers and tax authorities is to provide equality related to punishment and reward for the parties, errors in calculating the amount of tax that must be paid by taxpayers are not always caused by the taxpayer's fault, but the tax authorities in office can also make mistakes both physically and mentally. intentionally or not in determining the amount of tax.
\end{abstract}

Keywords: Taxpayer, Fiscus, Equality of Legal Position.

Jurnal Gagasan Hukum Vol. 02 | No.01 | Juni 2020 


\section{A. PENDAHULUAN}

Peradilan di bidang perpajakan di Indonesia belum mampu memenuhi rasa keadilan dan kesamaan kedudukan hukum (equality before the law), diantaranya disebabkan inkompetensi penegakan hukum dan kesalahan dalam perumusan konsep upaya hukum. Pengajuan upaya hukum berpotensi pada dijatuhkannya sanksi yuridis/administratif berupa denda bagi Wajib Pajak pencari keadilan. Di lain sisi, gesekan antara Wajib Pajak dengan Fiksus potensial terjadi dikarenakan kelemahan pemerintah dalam menjalankan sistem self assessment dan kelemahan peradilan pajak untuk menghasilkan output yang berkualitas.

Filosofi upaya hukum adalah sebagai sarana bagi seluruh pencari keadilan untuk memperjuangkan haknya secara equal di hadapan hukum. Tidak terkecuali Wajib Pajak yang juga memiliki kewajiban dan hak yang diatur oleh undang-undang. Di bidang perpajakan, upaya hukum terlembagakan diantaranya melalui Keberatan dan Banding. Keberatan adalah upaya yang dapat diajukan oleh Wajib Pajak atas sengketa pajak mengenai jumlah pajak terutang kepada Dirjen Pajak ${ }^{1}$. Apabila Wajib Pajak tidak puas dengan Keputusan Keberatan, maka Banding

1 Hadi Buana, Peradilan Pajak Sebagai Penyelesaian Sengketa Pajak, (Jakarta : IndHill Co, 2012), hlm.76. menjadi upaya hukum selanjutnya yang dapat diajukan oleh Wajib Pajak kepada Pengadilan Pajak. Anomali terjadi, dimana Pasal 25 ayat (9) Undang-undang Nomor 28 Tahun 2007 tentang Ketentuan Umum Tata Cara Perpajakan, yang berbunyi sebagai berikut ${ }^{2}$

"Dalam hal Keberatan Wajib Pajak ditolak atau dikabulkan sebagian dan Wajib Pajak tidak mengajukan permohonan Banding, jumlah pajak berdasarkan Keputusan Keberatan dikurangi dengan pajak yang telah dibayar sebelum mengajukan Keberatan harus dilunasi paling lama 1 (satu) bulan sejak tanggal penerbitan Surat Keputusan Keberatan, dan penagihan dengan Surat Paksa akan dilaksanakan apabila Wajib Pajak tidak melunasi utang pajak tersebut. Disamping itu, Wajib Pajak dikenai sanksi administrasi berupa denda sebesar 50\% (lima puluh persen)".

Ketentuan pasal ini menghilangkan kesamaan kedudukan hukum bagi Wajib Pajak dalam memperjuangkan haknya untuk mendapatkan keadilan. Pasal di atas bertentangan dengan keutamaan upaya hukum sebagai bentuk hak, maka seharusnya upaya hukum menjadi sebuah pilihan yang memberi keleluasaan bagi Wajib Pajak untuk menggunakan atau

\footnotetext{
2 Perubahan ketiga Undang-undang Nomor 6 Tahun 1983 Tentang Ketentuan Umum Tata cara Perpajakan, terakhir diubah dengan Undangundang Nomor 16 Tahun 2009.
} 
tidak menggunakan upaya hukum tersebut. Sengketa pajak timbul akibat ketidaksamaan sudut padang terhadap suatu perhitungan ataupun cara menghitung besaran pajak yangi harus dibayarkan. Kesalahan dalam perhitungan pajak tidak semata tibul akibat kelalaian Wajib Pajak, kesalahan dapat juga timbul akibat dari kesalahan Fiskus dalam melakukan penetapan besaran pajak yang harus dibayarkan oleh Wajib Pajak, baik disengaja ataupun tidak. Dalam posisi kesalahan muncul dari pihak Fiskus dan tidak dapat diterima oleh Wajib Pajak, Wajib Pajak menyampaikan permohonan Keberatan yang disampaikan kepada atasan Fiskus tersebut. Namun karena antara Fiskus dan atasannya adalah merupakan satu kesatuan, maka akan sangat sulit untuk dipercaya hasil yang diterbitkan kesatuan itu, fiskus melawan dirinya sendiri atas Keberatan yang diajukan oleh Wajib Pajak dikarenakan kesalahan dari pihak Fiskus. Sehingga sangat mungkin keadilan tidak akan dapat diraih, dan dalam posisi ini sangat tidak equal bila ancaman sanksi hanya dibebankan kepada Wajib Pajak saja.

Pembayaran disyaratkan 50\% (lima puluh persen) dari pajak yang terhutang, bila banding itu dilakukan terhadap besarnya pajak yang terutang, maka hal ini tidak dapat dibenarkan, sebab terjadinya tunggakan pajak tidak selalu disebabkan oleh kesalahan Wajib Pajak karena tidak melunasi pajak terhutang, tetapi dapat juga terjadi karena penetapan pejabat pajak berdasarkan ketetapan pajak yang dibuat berdasarkan kewenenangan dalam jabatan oleh pejabat pajak (fiskus).

Ketika pajak yang terhutang sebagai penetapan pajak dari pejabat pajak berdasarkan kewenangan jabatan adalah benar, maka hal tersebut bukan merupakan persoalan hukum. Akan tetapi bila sebaliknya, kalau penetapan mengenai pajak yang terhutang dalam ketetapan pajak secara jabatan tidak benar, maka pejabat dimaksud berarti telah melakukan tindakan yang melaggar hukum. Apabila dalam hal tersebut diajukan Banding, berarti pembanding (Wajib Pajak) harus membayar $50 \%$ dari pajak yang terhutang karena kesalahan pejabat pajak, tetapi yang memikul akibat negatifnya adalah pembanding (Wajib Pajak), sehingga tidak dapat dibenarkan materi pada Pasal 36 ayat (4) Undang-undang Nomor 14 Tahun 2002 tentang Pengadilan Pajak. ${ }^{3}$

Selanjutnya dampak negatif secara yuridis dan administratif bilamana Wajib Pajak berupaya mencari keadilan melalui Banding, maka Pasal 27 ayat (5d) mengenakan denda sebesar $100 \%$ dari besarnya pajak berdasarkan Keputusan

${ }^{3}$ Muhammad Djafar Saidi \& Eka Merdekawati Djafar Kejahatan di Bidang Perpajakan, (Jakarta : Rajawali Pers, 2011),hlm.177. 
Banding dikurangi dengan pajak yang telah dibayar sebelum mengajukan Keberatan, bagi Wajib Pajak yang Bandingnya ditolak atau dikabulkan sebagian, berikut kutipan materi muatan Pasal 27 ayat (5d) Undang-undang Nomor 28 Tahun 2007 tentang Ketentuan Umum Tata Cara Perpajakan :

"Dalam hal permohonan Banding ditolak atau dikabulkan sebagian, Wajib Pajak dikenai sanksi administrasi berupa denda sebesar $100 \%$ (seratus persen) dari jumlah pajak berdasarkan Putusan Banding dikurangi dengan pembayaran pajak yang telah dibayar sebelum mengajukan keberatan".

Ketentuan lebih lanjut, apabila Wajib Pajak memilih untuk menggunakan pilihan itu, maka layaknya hak, sepatutnya tidak diikuti dengan sanksi sebagai konsekuensi yuridis atau administratif dari penggunaan sebuah hak. Terlebih pada realisasi hak di dalam penegakan hukum diantara para pihak yang salah satunya memiliki posisi dominan, dimana warga negara diposisikan berhadapan dengan negara yang lebih superior. Bila Dirjen Pajak tetap bersikukuh dengan penghitungannya, makanWajib Pajak akan mendapat pinalti berupa denda $100 \%$ dari kekurangannya. Ketentuan ini jelas akan mengakibatkan ketakutan bagi masyarakat untuk mengajukan upaya hukum ini yang sebenarnya adalah hak masyarakat dalam kehidupan demokrasi. Sanksi yang terlalu tinggi akan mengakibatkan trauma. ${ }^{4}$

Bahwa materi muatan dalam Pasal 25 ayat (9) dan Pasal 27 ayat (5d) Undangundang Nomor 28 Tahun 2007 tentang Ketentuan Umum Tata Cara Perpajakan sebagaimana telah dirubah terakhir dengan Undang-undang Nomor 16 Tahun 2009 tersebut di atas bertentangan dengan Undang Undang Dasar Negara Republik Indonesia Tahun 1945 Pasal 27 ayat (1) dan Pasal 28D ayat (1).

"Segala warga negara bersamaan kedudukannya di dalam hukum dan pemerintahan dan wajib menjunjung hukum dan pemerintahan itu dengan tidak ada kecuali." (Pasal 27 ayat (1)).

"Setiap orang berhak atas pengakuan, jaminan, perlindungan, dan kepastian hukum yang adil serta perlakuan hukum yang sama di hadapan hukum.” (Pasal 28D ayat (1)).

Selain bertentangani dengan Undang Undang Dasar Negara Republik Indonesia Tahun 1945, maka Pasal 25 ayat (9) dan Pasal 27 ayat (5d) Undang-undang Nomor 28 Tahun 2007 tentang Ketentuan Umum Tata Cara Perpajakan sebagaimana telah diubah terakhir dengan Undang-undang Nomor 16 Tahun 2009 juga bertentangan

\footnotetext{
4 Adi Suliantoro, "Kajian Terhadap UU No. 28 Tahun 2007 tentang Ketentuan Umum dan Tata Cara Perpajakan", dalam Jurnal Fokus Ekonomi Fakultas Hukum Universitas Stikubank Semarang, Vol.7 No.1 April 2008, ISSN: 1412-3851, hlm.3643.
} 
dengan Undang-undang Nomor 39 Tahun 1999 tentang Hak Asasi Manusia Pasal 3 ayat (2) yang menyatakan bahwa :

"Setiap orang berhak atas pengakuan, jaminan, perlindungan dan perlakuan hukum yang adil serta mendapat kepastian hukum dan perlakuan yang sama di depan hukum."

Kesediaan Fiskus dan hakim untuk tunduk pada perspektif Undang-undang Nomoru28 Tahun 2007 tentang Ketentuan Umum Tata Cara Perpajakan tersebut dilatas menyebabkan peradilan yang seharusnya membantu menyeleksi kebenaran substantif di dalam penyelesaian sengketa pajak, tidak mampu menjadi instrumen yang fair bagi para pencari keadilan. Kesalahan dalam perumusan konsep upaya hukum turut menyebabkan disfungsi peradilan. Persoalan itu diikuti dengan kemampuan peradilan itu sendiri dalam menghasilkan produk yang memberi keadilan bagi Wajib Pajak yang masih patut dipertanyakan.

Saat sengketa pajak timbul sebagai akibat ketidak optimalan sistem, maka tidak ada pilihan bagi Wajib Pajak selain mencari perlindungan hukum dari negara, yang dibentuk untuk melindungi seluruh warganya. $^{5}$ Indonesia memilih

\footnotetext{
5 Salah satu landasan filosofi pemungutan pajak adalah Teori Bakti atau Teori Kewajiban Pajak Mutlak, yang menjelaskan mengenai hubungan erat antara rakyat dengan negara dimana negara dibenarkan untuk memungut pajak dari rakyat
}

mendeklarasikan diri sebagai Negara Hukum dan Negara Kesejahteraan (welfare state), yang berdasarkan Konstitusi (Alinea ke IV Pembukaan Undang Undang Dasar Negara Republik Indonesaia Tahun 1945) diantaranya mempunyai tujuan untuk membentuk suatu Pemerintah Negara Indonesia yang melindungi segenap bangsa Indonesia, tidak terkecuali dalam masalah perpajakan. Atas dasar itu, maka campur tangan negara dalam hal ini melalui judicial control mutlak diperlukan. Terutama dalam pemungutan pajak yang melibatkan tindakan dalam ranah hukum publik dimana keputusan bersifat sepihak (eenzijdig besluit). Pembatasannya adalah bahwa tujuan campur tangan yang dimaksudkan yaitu untuk terselenggaranya keadilan. Pelaksanaan kontrol oleh peradilan atas pelaksanaan oleh administrator (Fiskus) merupakan bagian yang paling sulit, meskipun fundamental. ${ }^{6}$

Instrumen bagi Wajib Pajak untuk mencari perlindungan dari negara yaitu dengan mengajukan upaya hukum. Pada tahap terdini, Wajib Pajak dapat mengajukan Keberatan. ${ }^{7} \quad$ Upaya ini didasarkan pada asumsi bahwa tindakan ini

karena Negara mengemban tugas untuk melindungi segenap warganya

6 Syofrin Syofyan dan Asyhar Hidayat, Hukum Pajak dan Permasalahannya, (Bandung : Refika Aditama, 2004), hlm.89.

7 Konsep Keberatan adalah sebagai upaya administratif, namun seperti telah dikemukakan di atas bahwa Keberatan dikualifikasikan sebagai peradilan semu atau peradilan tidak murni. 
bermotivasi

finansial,

yaitu

memperhitungkan biaya dan keuntungan yang diperoleh. Wajar bila pencari keadilan mempertimbangkan faktor-faktor ekonomis karena segala upaya di bidang perpajakan memang ditujukan untuk mempertemukan selisih pendapat antaran Wajib Pajak dengan Fiskus mengenai besaran jumlah pajak terutang. Hampir dapat dipastikan tujuan mengajukan Keberatan adalah untuk mendapatkan penyesuaian (pengurangan) atas penetapan jumlah pajaknya, atau untuk memperjuangkan pengembalian (restitusi) atas kelebihan pembayaran pajak.

Atas dasar tujuan di atas, maka salah satu pertimbangan logis sebelum mengajukan Keberatan adalah konsekuensi bila Keberatan ditolak atau hanya dikabulkan sebagian, yaitu penjatuhan denda sebesar 50\%. Persentase sepadan yang ditentukan Undang-undang Nomor 28 Tahun 2007 tentang Ketentuan Umum Tata Cara Perpajakan menganut prinsip "pukul rata", dalam artian Keberatan yang dikabulkan sebagian maupun yang ditolak sama-sama dikenai sanksi dengan persentase yang besar. Rakyat ibarat berada dalam situasi simalakama, buruknya kualitas pemeriksaan tidak dapat dijadikan patokan dalam melaksanakan kewajibannya. Selain itu, penetapan jumlah pajak tanpa didasari data yang akurat dan riil tentu akan mencederai rasa keadilan masyarakat. Namun, jika ingin memperjuangkan keadilan maka Wajib Pajak harus mengajukan Keberatan, "berkelahi” melawan nagara yang diwakili oleh Dirjen Pajak. Berdasarkan karakteristiknya, Keberatan dapat dikatakan sebagai quasi peradilan atau peradilan semu. $^{8}$ Di dalamnya terdapat perselisihan hukum (sengketa) dan ada aturan hukum yang dapat digunakan untuk menyelesaikannya, namun pihak yang bersengketa, yaitu Dirjen Pajak, sekaligus berkedudukan sebagai pihak yang memutus. Hal itu secara konseptual sesuai dengan bentuk Keberatan sebagai upaya administratif, namun secara realita tentu akan mempengaruhi kualitas keputusan. Aparat penelaah Keberatan secara alamiah memiliki conflict of interest, sehingga dapat diibaratkan seperti membedah tubuh sendiri. Begitu juga dengan Dirjen Pajak dihadapkan pada kebutuhan merealisasikan target pajak yang setiap tahunnya selalu ditetapkan meningkat. Permasalahan itu ditambah dengan rendahnya pengawasan penyelesaian proses Keberatan dan evaluasi atas Keputusan. Rendahnya kualitas produk Keberatan mendorong para

\footnotetext{
8 Unsur-unsur peradilan (administrasi) murni seperti dirumuskan oleh Rochmat Soemitro meliputi : (1) adanya suatu perselisihan hukum yang konkret; (2) adanya suatu aturan hukum yang abstrak yang mengikat umum dan dapat diberlakukan pada perselisihan hukum itu; (3) ada para pihak yang minimal terdiri dari dua pihak; dan (4) adanya suatu aparatur perangkat peradilan yang berwenang memutuskan disput.
} 
pencari

keadilan

untuk

mengajuka upaya hukum ke jenjang yang lebih tinggi, yaitu Banding. Yurisdiksi untuk memeriksa dan memutus sengketa Banding ada pada Pengadilan Pajak sebagai pengadilan khusus yang berada dalam lingkungan Peradilan Tata Usaha Negara. Banding merupaka upaya hukum biasa yang terakhir dan Peninjauan Kembali merupakan upaya hukum luar biasa bagi wajib pajak yang ingin memperjuangkan haknya, karena sesuai dengan sifat Pengadilan Pajak sebagai pengadilan tingkat pertama dan terakhir dalam memeriksa dan memutus sengketa pajak, yang seakan diperintahkan harus memenangkannya dengan berbagai cara akibat rasa takut dari ancaman denda administratif. Sejalan dengan itu, Putusan Pengadilan Pajak merupakan definietive beslissing en hebben permanente rechtskracht. Atas dasar itu, maka Banding menjadi tumpuan harapan bagi para pencari keadilan. Namun, keutamaan itu tidak diimbangi dengan kualitas putusan Banding yang belum merefleksikan keadilan. Sama halnya dengan realita Keberatan, bila dirunut ada asumsi kuat bahwa Putusan Banding yang tidak fair potensial berkaitan dengan dependensi lembaga. Pengadilan Pajak hingga kini masih tunduk pada otoritas dua kepala, menyalahi ketentuan Undang-undang Kekuasaan Kehakiman.
Namun, ditengah ketiadaan jaminan itu, undang-undang menentukan sanksi dengan ancaman sanksi yang tinggi, yaitu denda $50 \%$ (lima puluh persen) dalam Keberatan dan denda 100\% (seratus persen) dalam Banding jika Wajib Pajak kalah. Sedangkan jika Fiskus yang kalah, Fiskus hanya dibebani bunga sebesar $2 \%$ (dua persen) perbulan. Di dalam hukum dikenal adagium summun ius summa injuria, artinya menuntut hukum dilaksanakan secara ekstrem justru akan menyebabkan luka yang terdalam. ${ }^{9}$ Untuk menghindari hal itu, maka hukum (pajak) terlebih dahulu harus memiliki kemampuan yang memadai. Seperti telah diuraikan di atas, masalah kemampuan ini benar-benar merupakan masalah krusial di dalam dinamika hukum perpajakan di Indonesia. Kemampuan itu ditentukan oleh kemampuan komponenkomponennya, salah satunya Lembaga peradilan. Lemahnya komponen itu akan mempengaruhi kemampuan otonom dari hukum untuk menjalankan fungsinya dalam mewujudkan keadilan.

\section{B. METODE PENELITIAN}

Bahwa penelitian hukum sebagai suatu proses menemukan aturan hukum, prinsip-prinsip hukum, maupun doktrindoktrin hukum guna menjawab isu-isu

\footnotetext{
9 Sidarta Sakirno, Butir-butir Pemikiran Dalam Hukum : Memperingati 70 Tahun Prof.Dr.B .Arief Sidhartha, SH., (Bandung : Refika Aditama, 2008), hlm. 121.
} 
hukum yang dihadapi ${ }^{10}$. Oleh karena itu, dalam penelitian ini, Penulis menggunakan penelitian yuridis normatif.

\section{HASIL DAN PEMBAHASAN}

Pada Hasil dan Pembahasan memuat uraian tentang analisis hasil penelitian untuk memberikan jawaban/solusi terhadap masalah penelitian. Apabila terdapat rincian sesuai dengan permasalahan yang dibahas, maka dapat menggunakan penulisan sub bab seperti di bawah ini.

Hukum mesti dilaksanakan dan ditegakkan. Bagaimanapun hukumnya itulah yang harus berlaku, dan harus dilaksanakan serta tidak boleh menyimpang. Demikian menurut adagium fiat justicia et pereat mundus (meskipun dunia runtuh hukum harus ditegakkan), atau lex dura sedtamen scripta (hukum adalah keras, dan memang itulah bunyinya atau keadaannya, semua itu demi kepastian di dalam penegakannya).Dengan cara demikian, maka ada kepastian hukum dan kepastian hukum akan menciptakan tertib masyarakat, karena menurut Sudikno Mertokusumo, tujuan hukum adalah menciptakan kepastian hukum demi ketertiban masyarakat. ${ }^{11}$

\footnotetext{
${ }^{10}$ Peter Mahmud Marzuki, Penelitian Hukum, Cet.2, (Jakarta : Kencana, 2008), hlm.35.

11 Sudikno Mertokusumo dan A. Pitlo, Bab-Bab Tentang Penemuan Hukum, (Jakarta : Citra Aditya Bhakti, 1993), hlm.1-2.
}

Demi kepastian hukum itulah, maka ada yang berpendapat bahwa menegakkan hukum sama artinya dengan menegakkan undang-undang. Pendapat ini dipengaruhi oleh pandangan bahwa hukum tidak lain dari rangkaian norma-norma positif dalam sistem perundang-undangan. Kondisi ini tidak salah karena sistem hukum positif di Indonesia menganut atau dipengaruhi oleh system hukum Belanda yang sudah terbiasa dengan sistem tertulis, dan atas dasar konkordansi sistem hukum yang dibangun oleh negara Indonesia memang menganut sistem hukum tertulis. Kondisi inipun tidak salah karena paham hukum tertulis sangat dipengaruhi oleh positivisme hukum yang memandang hakekat hukum tidak lain dari pada norma-norma positif dalam sistem perundang-undangan. ${ }^{12}$ Pandangan tentang hukum yang demikian itu, menurut Satjipto Rahardjo lalu menjadi bersifat optic preskriptif, yaitu memandang hukum hanya sebagai system kaidah yang penganalisisnya terlepas dari landasan kemasyarakatannya. Dengan kata lain, Ilmu Hukum hanya dipandang sebagai sebuah eksemplar normologi saja untuk menghasilkan pola "problem solving" yang hanya menciptakan kemahiran sebagai tukang, yakni ahli-ahli hukum yang mahir

\footnotetext{
12 Anthon F. Susanto, Butir-Butir Pemikiran dalam Hukum, (2008), hlm.11.
} 
menafsirkan dan menerapkan hukum positif. $^{13}$

Pandangan positivisme hokum berpengaruh terhadap kemerdekaan kekuasaan kehakiman dalam menegakkan hukum, karena hakim sebagai pelaksana kekuasaan kehakiman pada saat ia melaksanakan fungsi yudisialnya di dalam memeriksa, mengadili, dan memutus perkara, terikat pada penerapan hokum positif, sehingga hakim di dalam penegakan hukum sebatas berfungsi sebagai penegak undang-undang. Pandangan positivisme hukum melahirkan legisme hukum pada hakim. Di sini peran hakim hanyalah sebagai corong undang-undang (Ia bouche des lois). Hakim hanya subsumtie automat penerap pasal undang-undang, sehingga penegakkan hukum oleh hakim dalam proses peradilan tidak sama dengan penegakkan keadilan, karena hakim hanya mengedepankan kepastian hukum melalui pendekatan legalistik formal pada ketentuan undang-undang. Berdasarkan kajian positivism itulah Mahkamah Konstitusi berpendapat bahwa Pasal 25 ayat (9) dan Pasal 27 ayat (5d) UU 28/2007 sama sekali tidak mengatur pemberlakuan yang membeda-bedakan antara wajib pajak yang satu dengan wajib pajak yang lain dalam pengenaan sanksi administrasi. Dalam

\footnotetext{
${ }^{13}$ Satjipto Rahardjo, Pemanfaatan IImu-ilmu Sosial Bagi Pengembangan IImu Hukum, (1977), hlm.3578.
}

konteks Undang-Undang Perpajakan, hak yang dijamin dalam Pasal 28D ayat (1) UUD 1945 bukan berarti merupakan jaminan bahwa wajib pajak tidak dapat dikenakan sanksi administrasi berupa denda yang diatur dalam Undang-Undang Perpajakan. Pasal 25 ayat (9) dan Pasal 27 ayat (5d) UU 28/2007 justru selaras dengan Pasal 28D ayat (1) UUD 1945 mengingat ketentuan tersebut berlaku bagi semua wajib pajak yang mengajukan keberatan dan/atau banding ${ }^{14}$. Akibatnya dalam penegakan hukum, jika hakim hanya memperhatikan kepastian hukum, maka unsur keadilan akan terabaikan, disebabkan di dalam putusannya, hakim hanya menerapkan undang-undang, dan hasilnya adalah kebenaran formal. Dalam hal ini, hakim tinggal mencari dan menemukan hukum pada undang-undang untuk diterapkan dalam peristiwa konkrit yang telah dibuktikan adanya dalam proses peradilan, tidak perduli apakah ketentuan hukum yang terdapat dalam pasal-pasal undang-undang yang diterapkan tersebut memenuhi rasa keadilan atau tidak, bermanfaat atau tidak bagi pencari keadilan. Secara proses hukum (peradilan), sikap hakim yang seperti itu tidak salah. Kecuali di dalamnya ada pelanggaran prosedur hukum acara yang dilakukan (unprofesional conduct) atau ada

\footnotetext{
14 Putusan Mahkamah Konstitusi NOMOR 30/PUU-X/2012
} 
pelanggaran perilaku hakim pada saat melakukan fungsi yudisialnya(misalnya menerima suap), barulah hakim tersebut dikenai sanksi baik administrasi ataupun pidana atas kinerja dan perilakunya.

Faktor keadilan merupakan hal yang mendasari untuk dibentuknya peradilan di bidang pajak. Ketidakadilan dalam pemungutan pajak yang tidak sesuai dengan Undang-undang Perpajakan menimbulkan sengketa antara Wajib Pajak dengan pejabat yang berwenang. Pengadilan Pajak merupakan wadah untuk mencari keadilan dan pemulihan hak-hak Wajib Pajak. Hal ini menunjukan bahwa Pengadilan Pajak mempunyai komitmen untuk menyelesaikan sengketa perpajakan dengan cepat, agar tidak berlarut-larut.

Pengadilan Pajak memiliki sejarah dari masa ke masa, khususnya dalam tata peradilan Indonesia. $^{15}$ Dari mulai dibentuknya, hingga kini keberadaannya senantiasa menjadi sandaran bagi masyarakat pencari keadilan, khususnya dalam menyelesaikan sengketa pajak. Pengadilan Pajak pada masa sebelum kemerdekaan lebih dikenal dengan nama peradilan. Peradilan pajak adalah peradilan yang terkait dengan masalah administrasi pajak yang mempunyai tugas menyelesaikan sengketa atau perselisihan

\footnotetext{
${ }^{15}$ https://www.bphn.go.id/data/documents/naskahaka demikruutentangperubahanatasuuno.14tahun 2002tentang pengadilanpajak.pdf, hlm. 10. Diakses 29 Oktober 2019
}

yang timbul karena adanya perbedaan pendapat antara pemerintah di satu pihak dengan Wajib Pajak di lain pihak mengenai besarnya pajak yang ditetapkan.

\section{Penerapan Prinsip Kesamaan Kedudukan Hukum Dalam Penyelesaian Sengketa Pajak Menurut Peraturan Perundang- undangan Di Indonesia}

Sebagai negara hukum, hukum di Indonesia mempunyai peranan yang sangat mendasar bagi kehidupan bangsa dan negara, hal ini bermakna bahwa hukum harus menampilkan peranannya sebagai titik sentral dalam seluruh kehidupan orang perorangan maupun kehidupan berbangsa dan bernegara. ${ }^{16}$ Konsep negara hukum harus memiliki beberapa komponen yang ada di dalamnya. Julius Stahl menjelaskan ada empat elemen penting, diantaranya : 1) Perlidungan Hak Asasi Manusia; 2) Pembagian kekuasaan; 3) Pemerintahan berdasarkan undang-undang; dan 4) Adanya Peradilan Tata Usaha Negara.

Menurut M. Scheltema berpendapat bahwa : ${ }^{17}$ "setiap negara hukum terdiri dari empat asas utama yaitu asas kepastian hukum, asas persamaan, asas demokrasi,

\footnotetext{
${ }^{16}$ Mochtar Kusumaatmadja, Hukum Masyarakat dan Pembangunan Hukum Nasional, (Bandung : Bina Cipta, 1975), hlm. 27.

${ }_{17}$ Marwan Effendy, Kejaksaan Republik Indonesia Posisi dan Fungsinya dari Prespektif Hukum (Jakarta : Gramedia Pustaka Utama, 2005), hlm. 142 .
} 
asas bahwa pemerintah dibentuk untuk melakukan pelayanan terhadap masyarakat"

A.V. Dicey menjelaskan ada tiga ciri negara hukum yang diistilahkan dengan Rule of Law, yakni : 1) Supremacy of Law; 2) Equality Before the Law; dan 3) Due Process of Law. Selanjutnya, The Internaional Commision of Jurist mengatakan bahwa prinsip-prinsip negara hukum ditambah dengan prinsip peradilan bebas dan tidak memihak (Independence and Impartiality of Judiciary). ${ }^{18}$ Sejalan dengan ketentuan tersebut, maka salah satu prinsip penting negara adalah adanya jaminan kesederajatan bagi setiap orang di hadapan hukum (Equality Before The Law). Oleh karena itu setiap orang berhak atas pengakuan, jaminan, perlindungan, dan kepastian hukum yang adil, serta perlakuan yang sama di hadapan hukum. ${ }^{19}$

Menurut A.V. Dicey, negara hukum menghendaki kekuasaan pemerintahan itu berada di bawah kendali aturan hukum (the rule of law), dimana terdapat tiga unsur utama di dalamnya, yaitu : ${ }^{20}$

a. Supremacy of law, artinya bahwa yang mempunyai kekuasaan tertinggi di dalam negara adalah hukum/kedaulatan hukum.;

\footnotetext{
${ }^{18}$ http://www.jimly.com/makalah/namafile/135/Kons ep_Negara Hukum Indonesia.pdf. Diakses pada tanggal 04 September 2019.

19 Supriadi, "Etika dan Tanggung Jawab Profesi Hukum di Indonesia", (Jakarta: Sinar Grafika, , 2006) hlm. 127.

${ }^{20}$ A.V. Diecy, Pengantar Studi Hukum Konstitusi, (Bandung : Nusamedia, 2007), hlm.251.
}

b. Equality before the law, artinya persamaan dalam kedudukan hukum bagi semua warga negara, baik selaku pribadi maupun dalam kualifikasinya sebagai pejabat negara.;

c. Constitusion based on individual rights, artinya konstitusi itu bukan merupakan sumber dari hak-hak asasi manusia, dan jika hak-hak asasi manusia itu diletakkan dalam konstitusi itu hanya sebagai penegasan bahwa hak asasi itu harus dilindungi.

Equality before the law berasal dari pengakuan terhadap individual (freedom), bertalian dengan hal tersebut Thomas Jefferson menyatakan bahwa "that all men are created equal" terutama dalam kaitannya dengan hak-hak dasar manusia. ${ }^{21}$ Konsep equality before the law telah diintrodusir dalam konstitusi, suatu pengakuan tertinggi dalam sistem peraturan perundang-undangan di tanah air. Konsep kesamaan kedudukan hukum, dalam hukum positif sesuai kandungan dalam Pasal 27 ayat (1) UndangaUndang DasareNegara RepublikaIndonesia Tahun 1945 menyatakan bahwa sebagai warga negara bersamaan kedudukannya di dalam hukum dan pemerintahan wajib menjunjung hukum dengan tidak ada kecualinya. Prinsip ini

\footnotetext{
${ }^{21}$ http://id.answers.yahoo.com/question/index?qid=2 0100224114235AAkHjgq, diakses pada tanggal 11 Juli 2019.
} 
berarti persamaan di hadapan hukum (equality before the law) adalah untuk perkara yang sama. Dengan eksistensi Dirjen Pajak selaku hakim dalam mengambil atau menetapkan keputusan atas Keberatan pajak sekaligus selaku pemberi perintah dalam pemungutan pajak, serta pengadilan pajak di Indonesia sebagai salah suatu lembaga pengadilan yang bersifat khusus, tentunya diharapkan dapat berperan secara independen dalam penyelesaian sengketa perpajakan di Indonesia, hal yang sama dapat pula dilihat di dalam Pasal 28D ayat (1) Undang Undang Dasar Negara Republik Indonesia Tahun 1945 yang mengatakan "setiap orang berhak atas pengakuan, jaminan, perlindungan dan kepastian hukum yang adil serta perlakuan yang sama di hadapan hukum". Namun keberadaannya belum searah dengan sistem peradilan satu atap di Indonesia sebagaimana amanat Undang Undang Dasar Negara Republik Indonesia Tahun $1945^{22}$

Meninjau norma yang termuat dalam Pasal 2 Undang-undang Nomor 14 Tahun 2002 tentang Pengadilan Pajak, Pengadilan Pajak adalah badan peradilan yang melaksanakan kekuasaan kehakiman bagi Wajib Pajak atau penanggung pajak yang mencari keadilan terhadap sengketa pajak.

22 Ismail Rumadan, Eksistensi Pengadilan Pajak Dalam Sistem Peradilan di Indonesia, (Jakarta : Puslitbang Kumdil MA-RI), hlm.1.
Pasal 5 dan Pasal 11 ayat (1) Undangundang Nomor 14 Tahun 2002 tentang Pengadilan Pajak disebutkan bahwa pembinaan teknis peradilan bagi Pengadilan Pajak serta pengawasan umum terhadap hakim Pengadilan Pajak dilakukan oleh Mahkamah Agung, sedangkan pembinaan organisasi, administrasi, dan keuangan bagi Pengadilan Pajak dilakukan oleh Kementerian Keuangan.Hal ini menunjukkan status dan kedudukan Pengadilan Pajak yang tidak mandiri, sebagai lembaga peradilan yang menjalankan fungsi yudikatif Pengadilan Pajak juga berada di bawah kekuasaan eksekutif. Kedudukan Pengadilan Pajak yang berada di bawah dua atap dapat mengakibatkan tidak independennya kekuasaan kehakiman dalam memutus perkara. Posisi Kementerian Keuangan sebagai pintu keluar masuknya anggaran negara memiliki peran yang strategis sebagai katalisator keberhasilan reformasi birokrasi. Ironisnya, justru berbagai kasus korupsi yang terungkap belakangan ini bersumber dari instansi tersebut, terutama dari Direktorat Jenderal Pajak dan Bea Cukai. Dari sekian banyak kasus yang muncul terkait dengan perpajakan, lembaga yang turut menjadi sorotan publik adalah Pengadilan Pajak yang dinilai tidak independen karena berada di bawah dua 
atap. $^{23}$ Sebagaimana diatur dalam Pasal 4 Undang-undang Nomor 14 Tahun 2002 tentang Pengadilan Pajak, pembinaan teknis peradilan bagi Pengadilan Pajak dilakukan oleh Mahkamah Agung, namun pembinaan organisasi, administrasi dan keuangannya masih dilakukan oleh Kementerian Keuangan. Keadaan ini menjadi salah satu sebab yang menghambat independensi para hakim untuk dapat memutus sengketa pajak dengan adil. $^{24}$

Bila kita tinjau dari teori pemisahan kekuasaan, Montesquieu membuat analisis atas pemerintahan Inggris dan ia menyatakan bahwa ketika kekuasaan legislative dan eksekutif disatukan pada orang yang sama, atau pada lembaga tinggi yang sama, maka tidak ada kebebasan jika kekuasaan kehakiman tidak dipisahkan dari kekuasaan legislatif dan ekskutif. Dan pada akhirnya akan menjadi hal yang sangat menyedihkan bila orang yang sama atau lembaga yang sama menjalankan ketiga kekuasaan itu, yaitu menetapkan hukum, menjalankan keputusan-keputusan publik, dan mengadili kejahatan atau perselisihan para individu. $^{25}$

Salah satu prinsip pokok negara hukum adalah adanya peradilan yang bebas

\footnotetext{
${ }^{23}$ https://www.kompasiana.com/bachtiar_endra/550f ef67813311b62cbc6946/independensi-pengadiloanpajak, diakses pada tanggal 21 Oktober 2019.

${ }^{24}$ Ibid.

${ }^{25}$ Binsar Sitorus, Independensi Hakim Dalam Sistem Peradilan Pajak Di Indonesia, (Surabaya : Direktorat Jendral Pajak), hlm.31.
}

dan tidak memihak. Pasal 24 ayat (1) Undang Undang Dasar Negara Republik Indonesia Tahun 1945 menyatakan bahwa "Kekuasaan kehakiman merupakan kekuasaan yang merdeka untuk menyelenggarakan peradilan guna menegakkan hukum dan keadilan". Kekuasaan kehakiman seharusnya juga meliputi hal-hal yang berkaitan dengan penegakan hukum dan keadilan dalam penyelenggaraan sistem peradilan di pengadilan pajak.

Berdasarkan teori-teori tentang asas hukum, maka asas-asas kekuasaan kehakiman yang merdeka haruslah digali dari apa yang terkandung pada kaidahkaidah yang terdapat di dalam peraturan perundang-undangan yang mengaturnya. Dari peraturan perundang- undangan yang mengatur kekuasaan kehakiman tersebut, maka dapat ditemukan asas-asas kekuasan kehakiman yang merdeka, yaitu : asas kebebasan hakim; asas peradilan dilakukan "Demi Keadilan Berdasarkan Ketuhanan Yang Maha Esa“; asas sederhana, cepat dan biaya ringan; asas persidangan terbuka untuk umum; asas susunan persidangan majelis; asas objektivitas. $^{26}$ Asas objektivitas menghendaki bahwa penyelesaian sengketa akan baik dan dapat diterima oleh semua pihak jika dilakukan secara imparsial (tidak memihak), objektif

\footnotetext{
26 Damang Averroes Al-Khawarizmi, Hukum dan Keadilan, 2015, hlm.4.
} 
dan adil. Oleh sebab itu, hakim adalah pejabat negara yang tugas utamanya memberikan penyelesaian definitif terhadap konflik atau sengketa antar warga masyarakat, maupun antar warga masyarakat dengan pemerintah yang dihadapkan kepadanya secara imparsial, objektif, adil dan manusiawi. ${ }^{27}$

Penyelesaian perkara secara objektif dan tidak memihak dilandasi oleh Pasal 4 ayat (1) Undang-undang Nomor 48 Tahun 2009 tentang Kekuasaan Kehakiman menegaskan "Pengadilan mengadili menurut hukum dengan tidak membedabedakan orang", artinya hakim dalam memeriksa dan memutus perkara yang diajukan kepadanya haruslah objektif dan tidak boleh memihak kepada pihak tertentu. Harapan-harapan di atas, muncul sebagai akibat dari adanya asas equality before the law yang merupakan salah satu dari 3 (tiga) arti dari rule of law (negara hukum) selain supremacy of law dan results of ordinary law of the land yang dikemukakan oleh AV. Dicey. ${ }^{28}$

Hal lain yang perlu diperhatikan sebagai wujud kehati-hatian terhadap asas independensi hakim adalah kebebasan hakim yang merupakan alat agar lahir putusan yang sebaik-baiknya tanpa ada

\footnotetext{
${ }^{27}$ B. Arief Shidarta, Sebuah Catatan tentang Hakim, (Cirebon, 2011), hlm.2.

${ }^{28}$ Albert Venn Divey, Introduction to the Study of the Law of the Contitution, (London : McMilian,1915), hlm.110-115.
}

pengaruh dari luar, dan di sisi lain kebebasan tersebut terkadang membahayakan kalau disalahgunakan menjadi alat untuk kesewenang-wenangan, yaitu atas nama kebebasan tersembunyi kepentingan dan keberpihakan. $^{29}$

Hakim pada Pengadilan Pajak diharuskan memerlukan tenaga-tenaga hakim khusus yang mempunyai keahlian khusus di bidang perpajakan dan berijazah sarjana hukum atau sarjana lain. Pada prakteknya, hakim pada Pengadilan Pajak sebagian besar adalah mantan pejabat pada Departemen Keuangan khususnya Direktorat Jenderal Pajak dan bukan hakim karir yang berasal dari system pembinaan karir pada umumnya. Selain itu, pembinaan terhadap hakim Pengadilan Pajak memang bukan di bawah Mahkamah Agung, namun di bawah Departemen Keuangan. Banyak kalangan yang mengkhawatirkan bahwa keadaan ini akan memengaruhi independensi hakim dalam memeriksa dan memutus perkara. ${ }^{30}$ Ketika sebuah vonis pengadilan dijatuhkan, pastilah akan ada pihak yang senang dan kecewa, ketika hakim membebaskan atau menghukum seseorang dan menolak atau mengabulkan

Bagir Manan, Enam Harapan Masyarakat Terhadap Lembaga Peradilan yang Perlu diberi Catatan, 2007.

${ }^{30}$ Binsar Sitorus, Independensi Hakim Dalam Sistem Peradilan Pajak di Indonesia, (Surabaya : Direktorat Jendral Pajak), hlm.39. 
sebuah gugatan. $^{31}$ Pengadilan Pajak lebih merupakan rezim dari Undang-undang Perpajakan, bukan merupakan rezim dari hukum tentang kekuasaan kehakiman. Tidak terdapat upaya hukum Banding maupun Kasasi mengakibatkan Putusan Pengadilan Pajak tidak mencerminkan adanya kepastian hokum dan rasa keadilan bagi masyarakat pencari keadilan. Kondisi ini menyebabkan kontrol terhadap pelaksanaan Pengadilan Pajak sangat lemah. $^{32}$

Pada masa reformasi, masyarakat menuntut transparansi, kebebasan, demokratisasi dan persamaan kedudukan di muka hukum, berdampak pada penyelenggaraan peradilan. Prinsip Kesamaan Kedudukan Hukum menghendaki tidak ada warga negara yang mendapat privilege termasuk di dalam bidang peradilan pajak, baik selaku pribadi maupun dalam kualifikasinya sebagai pejabat negara. Konsep negara hukumum rupakan perpaduan yang menghendaki kekuasaan negara ataupun kedaulatan harus dilaksanakan sesuai hukum, begitu pula sebaliknya.

Konsep keadilan sosial tidak ada pemisahan antara hak sipil politik dengan hak ekonomi sosial dan budaya. Kedua

\footnotetext{
31 Mahfud MD., Hukum Tak Kunjung Tegak (Tebaran Gagasan Otentik), Cet.1, (Bandung : PT. Citra Ditya Bakti), hlm.83.

${ }^{32}$ Ismail Rumadani, Eksistensi Pengadilan Pajak Dalam Sistem Peradilan di Indonesia, (Jakarta : Puslitbang Kumdil MA-RI), hlm.1.
}

induk Hak Asasi Manusia ini harus sejalan beriringan, tidak ada yang diprioritaskan dalam pelaksanaannya. Tentang Equality Before The Law bukan hanya dalam salah satu hak saja. Hak di bidang politik misalnya, hak dasar di bidang politik tercermin dalam Pasal 28 Undang-Undang Dasar Negara Republik Indonesia Tahun 1945 bahwa"kemerdekaan berserikat dan berkumpul, mengeluarkan pikiran dengan tulisan maupun lisan ditetapkan dalam undang-undang”. Selanjutnya Pasal 27 ayat (1), "Segala warga negara bersamaan kedudukannya di depan hukum dan pemerintahan dengan tidak ada kecualinya." Penjelasan pasal itu menegaskan prinsip penting bahwa Indonesia adalah negara hukum dan diperkuat dalam amandemen Pasal 1 ayat (3) berbunyi "negara Indonesia adalah negara hukum".33

Walaupun negara Indonesia adalah negara hukum seperti yang telah dijelaskan dan tertuang di dalam konstitusi, tetapi harus diingat bahwa tujuan negara adalah keadilan sosial yang juga tertuang di dalam konstitusi. Pernyataan konstitusi yang terdapat di dalam bagian Pembukaan Undang Undang Dasar Negara Republik Indonesia Tahun 1945 yang dari awal berlaku sampai saat ini telah dilakukan

33 As'ad Said Ali, Negara Pancasila Jalan Kemaslahatan Bangsa, (Yogyakarta : Pustaka LP3ES, 2009), hlm.107. 
amandemen sebanyak empat kali dan masih berlaku, yakni; "kemudian dari pada itu untuk membentuk suatu pemerintahan negara Indonesia yang melindungi segenap bangsa Indonesia dan seluruh tumpah darah Indonesia, dan untuk memajukan kesejahteraan umum, mencerdaskan kehidupan bangsa, dan ikut melaksanakan ketertiban dunia yang berdasarkan kemerdekaan, perdamaian abadi, dan keadilan sosial, maka disusunlah kemerdekaan kebangsaan Indonesia itu dalam suatu Undang Undang Dasar Negara Republik Indonesia, yang terbentuk dalam suatu susunan Negara Republik Indonesia yang berkedaulatan rakyat dengan berdasarkan kepada Ketuhanan Yang Maha Esa, kemanusiaan yang adil dan beradab, persatuan Indonesia, dan kerakyatan yang dipimpin oleh hikmat kebijaksanaan dalam permusyawaratan/perwakilan, serta dengan mewujudkan suatu keadilan bagi seluruh rakyat Indonesia". ${ }^{34}$

Bahwa Undang-undang Nomor 14 Tahun 2002 tentang Pengadilan Pajak yang secara formal pembentukan undangundang tersebut telah memenuhi syarat sebagai undang-undang positif, tetapi ada beberapa pasal yang lebih menitik beratkan kepada kewajiban warga negara yang sepertinya mengandung nuansa bahwa

34 Redaksi Lima Sekawan, Lengkap UUD 1945 (dalam lintasan Amandemen) dan UUD (yang pernah berlaku) di Indonesia (sejak tahun 1945), (Jakarta : Lima Adi Sekawan, 2006), hlm.4. undang-undang tersebut lebih memperkuat kekuasaan pemerintahan atau negara di dalam memungut seluruh kewajiban warga negara. Dalam prinsip seperti itu, memang teorinya negara memiliki hak untuk meminta dan menerima kewajiban warga negara untuk kepentingan negara, tetapi itu semua harus dilandaskan pada penghormatan dan pengakuan prinsipprinsip Hak Asasi Manusia yang telah dimuat dalam materi muatan Undang Undang Dasar Negara Republik Indonesia Tahun 1945. Seharusnya beberapa pasal dan beberapa materi muatan di dalam Undang-undang Nomor 14 Tahun 2002 tentang Pengadilan Pajak harus juga mencerminkan pengakuan dan penghormatan terhadap setiap warga negara dan sekaligus juga menjamin rasa keadilan.

Undang-undang Nomor 14 Tahun 2002 tentang Pengadilan Pajak sarat dengan materi muatan yang melegitimasi kekuasaan pemerintah, kekuasaan negara terhadap warga negara, oleh karena itu pemisahan kekuasaan antara eksekutif, legislatif dan yudikatif harus dilakukan untuk menjamin adanya perimbangan kekuasaan yang saling mengontrol. Melalui Undang-undang Nomor 14 Tahun 2002 tentang Pengadilan Pajak, secara tidak langsung penyelenggara negara dan pemerintahan bertindak sesuai dengan 
kehendak yang bisa bersimpangan dengan rasa keadilan dan kepastian hukum.

Hubungan antara Wajib Pajak dan Fiskus seringkali berada dalam posisi tidak setara secara de facto, meskipun secara de jure kesetimbangan ini sudah diakomodasi di dalam Pasal 36A Undang-undang Nomor 28 Tahun 2007 tentang Ketentuan Umum Tata Cara Perpajakan. Akibat ketidakpahaman Wajib Pajak terhadap undang-undang dan cara pandang Fiskus yang salah, maka secara persepsi dan kenyataan praktikal masih sering dijumpai pola hubungan yang mendudukkan Wajib Pajak hanya sebagai obyek penderita dalam proses perpajakan. Pemilihan kata dan penjelasan yang tidak taktis menjadi satu indikasi bahwa mungkin paradigma dalam mendesain peraturan lebih cenderung terlihat mengedepankan persepsi-persepsi negatif terhadap salah satu pihak dalam proses ini.

Akibat dari ketidak jelasan suatu klausul dalam undang-undang juga bisa membawa dampak di tataran implementasinya. Sebagai contoh, mengartikulasikan itikad baik harus dapat dilakukan secara praktik dalam suatu cara yang dapat diterima oleh Fiskus maupun Wajib Pajak melalui mekanisme teknis yang sudah dikenal. Strategi membumikan klausul normatif menjadi common practice adalah bagian dari cara untuk memudahkan komunikasi yang baik antara dua pihak.
Misalnya upaya membumikan tersebut dapat dilakukan dengan mendefinisikan secara operasional klausul itikad baik dengan cara mendorong Wajib Pajak untuk menyampaikan hasil pembukuan yaitu Laporan Keuangan yang telah sesuai dengan standar akuntansi keuangan.

Kewajiban ini kemudian harus disediakan insentif maupun disinsentifnya. Meskipun tidak mudah, tetapi ada keyakinan kualitas komunikasi akan meningkat jika alat komunikasinya juga baik, dan di satu sisi dampak positifnya adalah terjadi kejelasan dan kesamaan pandangan dengan bahasa yang satu terhadap definisi itikad baik.

Di sisi lain, sebagai bentuk kesetaraan perlakuan agar terjadi hubungan yang sehat, maka Fiskus juga harus memperlihatkan itikad baik yang sepadan. Misalnya, undang-undang harus mensyaratkan adanya kewajiban melakukan peer-review secara berkala oleh pihak-pihak yang dianggap mampu untuk menguji kualitas pekerjaan Fiskus dalam pemeriksaan. Ini semua adalah teknik-teknik yang secara definisi dan praktik sudah dipahami secara jelas oleh para pelaku profesional di bidang yang terkait.

\section{PENUTUP}

Berdasarkan landasan teori dan penjabaran dalam Bab-bab sebelumnya bahwa Undang-undang Nomor 28 Tahun 2007 tentang Ketentuan Umum Tata 
Perpajakan tidak memberikan kepastian hukum yang adil bagi para pihak, posisi Fiskus sebagai "negara" memiliki kekuasaan (absolute power) untuk menghitung, menetapkan besaran pajak yang harus dilunasi oleh Wajib Pajak dan membuat keputusan atas permohonan Keberatan yang disampaikan oleh Wajib Pajak. Di satu sisi, absolut power yang ada ditangan Fiskus dapat saja disalahgunakan untuk mengejar keuntungan sepihak, karena yang memeriksa permohonan Keberatan Wajib Pajak adalah atasan langsung dari Fiskus yang melakukan pemeriksaan dan menetapkan besaran pajak tersebut.

Dan apabila wajib pajak mengajukan keberatandan/atau Banding, wajib pajak diancam dengan ancaman denda bila mereka dikalahkan.

Merujuk kepada Pasal 25 ayat (9) dan Pasal 27 ayat (5d) Undang-undang Nomor 28 Tahun 2007 tentang Ketentuan Umum Tata Cara Perpajakan, tidak mencerminkan prinsip Kesamaan Kedudukan Hukum (Wajib Pajak/warga negara dengan Fiskus dalam upaya memperoleh keadilan), ketentuan ini bertentangan dengan Pasal 27 ayat (1) Undang Undang Dasar Republik Indonesia Tahun 1945, pasal tersebut merupakan suatu barier terhadap warga negara yang ingin mencari keadilan. Bahwa materi muatan Pasal 25 ayat (9) dan Pasal 27 ayat (5d) Undang- Undang KUP merupakan ancaman bagi WP pencari keadilan, sehingga melanggar hak konstitusi, sebagaimana diatur dalam Pasal 28 Dayat (1), Pasal 28G ayat (1) UndangUndang Dasar 1945. Bahwa materi muatan Pasal 25 ayat (9) dan Pasal 27 ayat (5d) Undang-Undang KUP mempersulit bagi WP dalam upaya mencari keadilan, sehingga melanggar hak konstitusi, sebagaimana diatur dalam Pasal $28 \mathrm{H}$ ayat (2). Bahwa materi muatan Pasal 25 ayat (9) dan Pasal 27 ayat (5d) Undang-Undang KUP tidak sesuai dengan prinsip pemungutan pajak, yaitu menurut prinsip perlakuan yang sama, equality, dan keadilan (equity).

Bentuk ideal hubungan hukum Wajib Pajak dan Fiskus adalah dengan memberikan kesamaan terkait dengan punishment dan reward bagi para pihak, kesalahan perhitungan besaran pajak yang harus dibayarkan oleh Wajib Pajak tidak selalu disebabkan atas kesalahan pihak Wajib Pajak akan tetapi Fiskus secara jabatan juga dapat melakukan kesalahan baik secara sengaja ataupun tidak dalam menetapkan besaran pajak, sangat tidak ideal apabila kesalahan Fiskus itu harus dipikul oleh Wajib Pajak ketika permohonan Banding Wajib Pajak dikabulkan sebagian atau ditolak secara keseluruhan, yang notabenenya Keberatan tersebut diperiksa oleh atasan Fiskus tersebut. Namun seharusnya ancaman sanksi bagi Wajib Pajak untuk mencari 
keadilan sudah sepantasnya dihilangkan

karena bertentangan dengan prinsip Negara

hukum.

\section{DAFTAR PUSTAKA}

Adi Suliantoro, "Kajian Terhadap UU No. 28 Tahun 2007 tentang Ketentuan Umum dan Tata Cara Perpajakan", dalam Jurnal Fokus Ekonomi Fakultas Hukum Universitas Stikubank Semarang, Vol.7 No.1 April 2008, ISSN: 1412-3851

Anthon F. Susanto, Butir-Butir Pemikiran dalam Hukum, 2008

A.V. Diecy, Pengantar Studi Hukum Konstitusi, (Bandung : Nusamedia, 2007)

Bagir Manan, Enam Harapan Masyarakat Terhadap Lembaga Peradilan yang Perlu diberi Catatan, 2007.

Binsar Sitorus, Independensi Hakim Dalam Sistem Peradilan Pajak di Indonesia, (Surabaya : Direktorat Jendral Pajak)

B. Arief Shidarta, Sebuah Catatan tentang Hakim, (Cirebon, 2011)

Hadi Buana, Peradilan Pajak Sebagai Penyelesaian Sengketa Pajak, (Jakarta : IndHill Co, 2012)

Indonesia, undang-undang Nomor 6 Tahun 1983 Tentang Ketentuan Umum Tata cara Perpajakan, terakhir diubah dengan Undang-undang Nomor 16 Tahun 2009.

Ismail Rumadan, Eksistensi Pengadilan Pajak Dalam Sistem Peradilan di Indonesia, (Jakarta : Puslitbang Kumdil MA-RI)

Mahfud MD., Hukum Tak Kunjung Tegak (Tebaran Gagasan Otentik), Cet.1, (Bandung : PT. Citra Ditya Bakti),

Marwan Effendy, Kejaksaan Republik Indonesia Posisi dan Fungsinya dari
Prespektif Hukum (Jakarta : Gramedia Pustaka Utama, 2005),

Mochtar Kusumaatmadja, Hukum Masyarakat dan Pembangunan Hukum Nasional, (Bandung : Bina Cipta, 1975)

Muhammad Djafar Saidi \& Eka Merdekawati Djafar_Kejahatan di Bidang Perpajakan, (Jakarta : Rajawali Pers, 2011)

Putusan Mahkamah Konstitusi NOMOR 30/PUU-X/2012

Peter Mahmud Marzuki, Penelitian Hukum, Cet.2, (Jakarta : Kencana, 2008)

Satjipto Rahardjo, Pemanfaatan IImu-ilmu Sosial Bagi Pengembangan IImu Hukum, 1977

Sidarta Sakirno, Butir-butir Pemikiran Dalam Hukum : Memperingati 70 Tahun Prof.Dr.B.Arief Sidhartha, SH., (Bandung : Refika Aditama, 2008

Sudikno Mertokusumo dan A. Pitlo, Bab-Bab Tentang Penemuan Hukum, (Jakarta : Citra Aditya Bhakti, 1993

Supriadi, "Etika dan Tanggung Jawab Profesi Hukum di Indonesia", (Jakarta: Sinar Grafika, 2006)

Syofrin Syofyan dan Asyhar Hidayat, Hukum Pajak dan Permasalahannya, (Bandung : Refika Aditama, 2004.

https://www.bphn.go.id/data/documents/naskah akademikruutentangperubahanatasuuno.14 tahun 2002tentang pengadilanpajak.pdf,

http://www.jimly.com/makalah/namafile/135/K onsep_Negara_Hukum_Indonesia.pdf

http://id.answers.yahoo.com/question/index?qid $=20100224114235 \mathrm{AAkHjgq}$,

https://www.kompasiana.com/bachtiar_endra/5 50fef67813311b62cbc6946/independensipengadiloan-pajak, 